\title{
The Bupleurum (Apiaceae) feeding species of Trifurcula (Glaucolepis): new species, biology and distribution (Lepidoptera: Nepticulidae)
}

\author{
Zdeněk Laštůvka, Aleš Laštůvka \& Erik J. van Nieukerken
}

\begin{abstract}
The Bupleurum feeding species of Trifurcula (Glaucolepis) Braun, 1917 are revised. Five species are recognised: T. bupleurella (Chrétien, 1907), T. sanctibenedicti Klimesch, 1979, T. megaphallus van Nieukerken, Z. Laštůvka \& A. Laštůvka sp. n. feeding on Bupleurum gibraltarium in southern Spain, T. chretieni Z. Laštůvka, A. Laštůvka \& van Nieukerken sp. n. feeding on Bupleurum rigidum in southern France, Spain and Portugal, and T. siciliae Z. Laštůvka, A. Laštůvka \& van Nieukerken sp. n. feeding on B. fruticosum in Sicily. The group is restricted to southwestern Europe and northern Africa, the area where most shrubby Bupleurum species occur. A NJ and Bayesian analysis of DNA barcodes of four out of five species suggest a single origin of Bupleurum feeding in the subgenus Glaucolepis.

Zdeněk Laštůvka*, Mendel University, Zemedelská 1, CZ-613 00 Brno, Czech Republic.last@mendelu.cz

Aleš Laštůvka, Slavíčkova 15, Prostějov, Czech Republic

Erik J. van Nieukerken, Department of Terrestrial Zoology, Naturalis Biodiversity Center, PO Box 9517, NL-2300 RA Leiden, The Netherlands.

nieukerken@naturalis.nl
\end{abstract}

\section{Introduction}

The subgenus Glaucolepis Braun, 1917 of the genus Trifurcula Zeller, 1848 is diverse in the Mediterranean region, where the majority of the 30 named species is found. Whereas the type species, T. (Glaucolepis) saccharella (Braun, 1912), is the only known North American species of the genus, and a leafminer on Acer, the Mediterranean species make leaf- or stem-mines on small shrubs and herbs belonging to Lamiaceae, Plantaginaceae (genus Globularia), Apiaceae (genus Bupleurum) and single species on Linaceae (Linum) and Asteraceae (Launaea) respectively. A revision for the subgenus as a whole does not yet exist, but several recent papers treat a number of species taxonomically (Klimesch 1975, 1976, van Nieukerken \& Puplesis 1991, Laštůvka \& Laštůvka 1998, 2007, Laštůvka \& Laštůvka 2000, Ivinskis et al. 2012) and some papers review at least a sub- set of the (sub)genus (van Nieukerken \& Johansson 1990, Klimesch 1977, Laštůvka \& Laštůvka 1997, van Nieukerken et al. 2010). Hitherto two species were known to feed on the genus Bupleurum, a genus of Apiaceae with several shrubby species in the Mediterranean. Despite the fact that Apiaceae usually harbour large numbers of leafmines (most frequently caused by Diptera: Agromyzidae, eg. Ellis 2012), they are a very unusual hostplant family for Nepticulidae. The only other known nepticulid to feed on these plants is the taxonomically isolated and rare European Ectoedemia (Fomoria) viridissimella (Caradja, 1920) that feeds on Peucedanum cervaria (L.) Lapeyr. (van Nieukerken \& Johansson 1990, Laštůvka \& Laštůvka 1997). The known Bupleurum feeders are T. bupleurella (Chrétien 1907), reared from Bupleurum fruticosum and T. sanctibenedicti Klimesch 1979 from B. fruticescens. During our field- 
work in the western Mediterranean, we encountered leafmines on several other Bupleurum species, partly belonging to new taxa. We describe here three new species and provide new data for the known species, including DNA barcoding data for four out of the five species.

\section{Material and methods}

In the material lists we do not repeat records from France, Spain or Portugal that we published earlier (Laštůvka \& Laštůvka 2011, van Nieukerken et al. 2004, 2006). Adults were collected at various types of light (8 to $25 \mathrm{~W}$ fluorescent tubes, UV lamp $125 \mathrm{~W}$ ) or during the day by beating the host plants with a sweep net; mines with larvae were collected and partly reared, or larvae taken out and kept in ethanol for morphological or molecular analysis. The genitalia of both sexes were prepared in the usual way (e.g. van Nieukerken 1985, van Nieukerken et al. 1990), genitalia were either embedded in permanent slides, using euparal, or in small vials with glycerine. Watercolours and drawings were prepared by $\mathrm{AL}$, those of genitalia were often made from genitalia embedded in glycerine, which could be easier manipulated and then viewed from all sides. Photographs of moths, leafmines and genitalia slides were taken by EvN with a Zeiss AxioCam (HR or MR5) digital camera attached respectively to a Zeiss Stemi SV11 stereo-microscope and a Zeiss Axioskop H, using Carl Zeiss AxioVision software (version 4), for some photographs using the module "Extended focus". Hostplant names follow Hand (2011). Distribution maps were prepared with Dmap (Morton 2000).

For the sake of comparability the morphological terms follow our earlier treatments of the genus (e.g. Nieukerken \& Johansson 1990, Laštůvka \& Laštůvka 2007, van Ivinskis et al. 2012), even though the correct morphological term for aedeagus would be phallus and terminal cilia and cilia-line could better be termed fringe and fringe-line.

Material is either from the collection of A. Laštůvka (AL), or from one of the following museum collections: Musée Nationale de l'Histoire Naturelle, Paris (France), Naturalis Biodiversity Center, Leiden (RMNH), Staatliches Museum für Naturkunde Stuttgart (Germany), Zoologische Staatssammlung München (Germany), Zoological Museum, Natural History Museum of Denmark, Copenhagen (Denmark). We refer to the collections by their cities. The code RMNH is used for registry numbers in Leiden.

\section{DNA barcoding}

DNA was extracted from caterpillars or from dry adult abdomens. DNA extraction from larvae was usually destructive; from abdomens and some larvae the non-destructive protocol by Knölke et al. (2005) was followed, allowing the preparation of the genitalia or larval skin as well. Details of methods are presented by van Nieukerken et al. (2012), we provide here the COI DNA barcode for four out of the five species, only lacking Trifurcula siciliae sp. n. They are compared with and included in the recently published dataset of Glaucolepis barcodes (Ivinskis et al. 2012), with Trifurcula (s.s.) pallidella (Duponchel, 1843), type species of the genus, as outgroup. Data of all barcodes and vouchers can be found on the Barcode of Life webpages (http:// www.barcodinglife.com/views/login.php) under the dataset "Bupleurum feeding Trifurcula (Glaucolepis)" [doi: dx.doi.org/10.5883/DS-BUPGLAU]. We give here the specimen Registration numbers, and the Barcode Identification Number (BIN) for each species, and Genbank accession numbers when available. For the most recent records they were not yet available when going to press and can later be found in the BOLD dataset.

\section{Analysis}

Neighbor Joining (NJ) trees based on DNA barcode sequences of all available specimens were prepared with tools on BOLD (Ratnasingham \& Hebert 2007). Genetic distance calculations were performed using uncorrected P distance (Srivathsan \& Meier 2012).

A Bayesian Analysis was carried out with the same dataset in MrBayes 3.1.2 (Ronquist \& Huelsenbeck 2003). Each analysis was run twice, starting from random starting trees, for 1 million generations and sampling from the posterior every 1000 generations. No partition was used. A conservative burn-in of $25 \%$ was chosen.

\section{Taxonomy}

All species and hostplants are listed in Table 1.

\section{Trifurcula (Glaucolepis) bupleurella (Chrétien)}

Figs 1, 10, 15, 16, 20, 25, 26, 31, 32, 46

Nepticula bupleurella Chrétien 1907: 91. Syntypes (3): [France], Hérault, Aude, mines on Bupleurum fruticosum, September, adults emerged June, July, Chrétien (MNHN) [not examined].

Ectoedemia (Dechtiria) bupleurella: Klimesch 1975: 863 [redescription].

Trifurcula (Glaucolepis) bupleurella: van Nieukerken 1986: 15 [new combination]; Laštůvka \& Laštůvka 1997: 131 [re- 
Table 1. List of species and hostplants.

\begin{tabular}{ll}
\hline Trifurcula (Glaucolepis) bupleurella (Chrétien, 1907) & Bupleurum fruticosum $\mathrm{L}$. \\
Trifurcula (Glaucolepis) megaphallus sp. n. & Bupleurum gibraltarium Lam.* \\
Trifurcula (Glaucolepis) chretieni sp. n. & Bupleurum rigidum L. subsp. rigidum \\
& Bupleurum rigidum subsp. paniculatum (Brot.) H. Wolff \\
& Bupleurum fruticosum L. \\
Trifurcula (Glaucolepis) siciliae sp. n. & Bupleurum fruticescens L. subsp. fruticescens \\
Trifurcula (Glaucolepis) sanctibenedicti Klimesch, 1979 & Bupleurum fruticescens subsp. spinosum (Gouan) O. Bolòs \& Vigo
\end{tabular}

* Often incorrectly spelled as gibraltaricum.

description]; van Nieukerken et al. 2004: 231 [distribution Spain, Portugal]; van Nieukerken et al. 2006: 62 [distribution France].

\section{Diagnosis}

Recognised from other Bupleurum feeders by the combination of its size, large tornal spot and in male the absence of yellow androconial scales on forewing underside. Amongst other Trifurcula it resembles externally T. magna Laštůvka \& Laštůvka, 1997 of about the same size, but with different male and female genitalia (Laštůvka \& Laštůvka 1997, van Nieukerken et al. 2006), and the smaller T. cryptella (Stainton, 1856), although the latter has in the male also a long white hairpencil near frenulum. Females can sometimes be confused with Ectoedemia species, light collected material should be dissected.

\section{Description}

Male (Fig. 1). Wingspan 4.3-5.8 mm, forewing length $2.0-2.7 \mathrm{~mm}$. Frontal tuft orange yellow to dark ferruginous; scape completely white to ochreous or with just a few scattered brown scales, especially along edge, antenna with 38-41 segments. Thorax and forewing fuscous, dorsal margin paler, large ochreous tornal spot at two thirds. Cilia line distinct, terminal cilia silvery white. Forewing underside fuscous. Hindwing slightly widened, greyish; underside with velvet patch of androconial scales present, similarly as in other Trifurcula species. Abdominal tufts on segments $6-8$ yellow.

Female. Wingspan 4.9-6.0 mm, forewing length 2.2-2.8 mm. Antenna with 33-35 segments. Further as male, but without special scales and with narrower hindwing.

Male genitalia (Figs 10, 15, 16). Capsule length 240 $290 \mu \mathrm{m}$. Vinculum slightly concave anteriorly. Tegumen with triangular pseuduncus, slightly angled apically. Uncus with broad apical process. Gnathos with large, triangular central element. Valva 130-145 $\mu \mathrm{m}$ long, triangular, with convex inner margin and with long digitate apical process, slightly curved inwards. Aedeagus 285-290 $\mu \mathrm{m}$ long, slightly longer than capsule, with a stout, slightly sigmoid cornutus of 160-195 $\mu \mathrm{m}$ long.
Female genitalia (Figs 20, 25, 26). Total bursa length 835-950 $\mu \mathrm{m}$. Anal papillae distinct, rounded, with ca. 35 short setae each. T8 with groups of short setae and scales; S8 with two transversal rows of several long setae. Posterior and anterior apophyses of same length, thin. Signa about $310-365 \mu \mathrm{m}$, up to $6-$ 8 rows of cells wide, three times as long as wide. Ductus spermathecae distinct, with a long uncoiled part of same length as coiled part, the latter with 44.5 relatively wide convolutions.

\section{Biology}

Hostplant. Bupleurum fruticosum, a common evergreen shrub of garrigue and maquis, often on limestone.

Egg laid either on upper or lower leaf surface, but leafmine always in the upperside parenchyma.

Leafmine (Figs 31, 32) usually a long, only slightly enlarged gallery with a thin central frass line, but occasionally strongly enlarged into a blotch. Larvae found from January to October, probably the year around. Adults from May to August, probably in several generations.

\section{Distribution (Fig. 46)}

Southern France, Spain along Mediterranean coast and southern Portugal (van Nieukerken et al. 2004, 2006). To be expected in northern Africa.

\section{DNA barcodes}

One DNA barcode has been analysed of a male from France (RMNH.INS.23653, Genbank accession number JX261891) (BIN: BOLD:ABW9592).

\section{Remarks}

The record of vacated mines of this species on $B u$ pleurum rigidum (Chrétien 1907) refers to T. chretieni and earlier records from Sicily (Karsholt et al. 1995, Klimesch 1975) refer to T. siciliae, see below. Additional material. Spain: $10^{\top}, 1$, Málaga, Monda, 26.vi.2004, A. \& Z. Laštůvka (AL). 

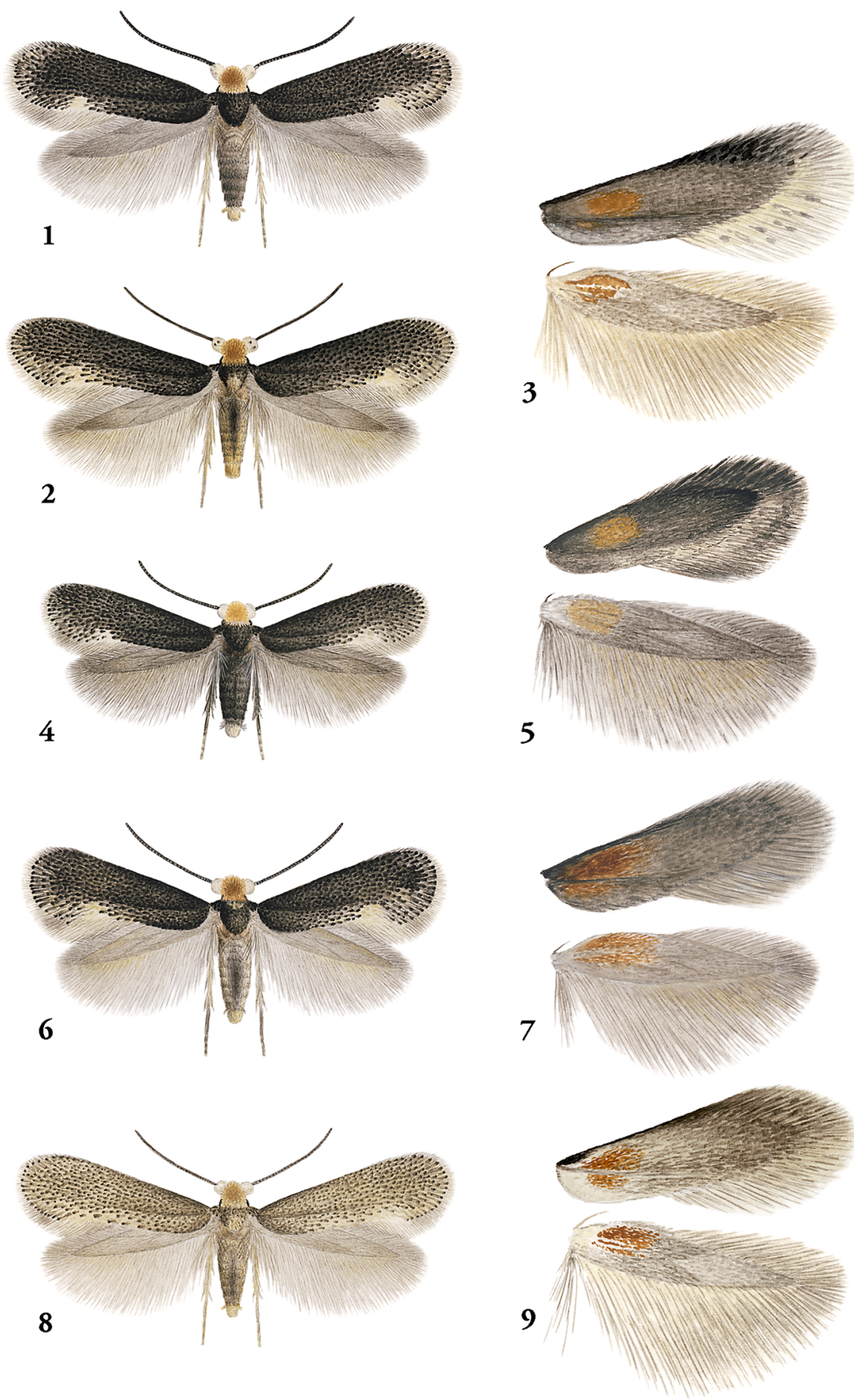

Figs 1-9. Trifurcula (Glaucolepis) species, males dorsal habitus and wing undersides. - 1, T. bupleurella, France, Aude, Sigean, el. iii.1999; 2, 3, T. megaphallus, Paratype, Spain, Málaga, Jimera de Líbar, e.l. vii.2001; 4, 5, T. chretieni, Holotype, Spain, Barcelona, Santa Maria d'Oló; 6, 7, T. siciliae, Paratype, Italy, Sicilia, Francavilla di Sicilia, e.l. vii.2000; 8, 9, T. sanctibenedicti, Spain, Zaragoza, Tosos, 12.vi.2006. 


\section{Trifurcula (Glaucolepis) megaphallus van} Nieukerken, Z. Laštůvka \& A. Laštůvka sp. n. Figs 2, 3, 11, 17, 21, 27, 28, 34, 44, 45, 47

Type material. Holotype $\sigma^{7}$. Spain, Málaga, Serrania de Ronda, roadsides $4 \mathrm{~km} \mathrm{~W}$ El Burgo, $900 \mathrm{~m}$, UTM: 30S UF2201172658, 29.ii.2000, on Bupleurum gibraltarium, limestone cliffs along road, e.l. 22.v.-2.vi.2000, EvN no 2000048, E.J. van Nieukerken, Genitalia slide JCK15168 (RMNH.INS. 15168) (Leiden).

Paratypes 910, 9o. Spain: $10^{7}$, same data as holotype; $50^{7}$, Almería, Sierra de los Filabres, Uleila del Campo, 26.vi.1992, A. \& Z. Laštůvka (AL); 107, ibidem, but 9.vii.1993; 30 , 19, ibidem, 9.vii.1993, larvae in leafmines on Bupleurum gibraltarium, e.l. viii.1993, A. \& Z. Laštůvka (AL, Leiden); 30", Cádiz, Sierra de Grazalema, 2 km NW Grazalema, 1140 m, UTM: 30S TF877729, 28.ii.2000, on Bupleurum gibraltarium, limestone cliffs along road, e.l. 25.v.-6.vi.2000, EvN no 2000041, E.J. van Nieukerken (Leiden); $10^{7}, 20$, Granada, $2 \mathrm{~km} \mathrm{~N}$ Cádiar, near Narila, $1150 \mathrm{~m}$, UTM: 30S VF8490, 11.i.1988, leafmines on Bupleurum gibraltarium, e.l. 13-15.v.1988, EvN no 88021, E.J. van Nieukerken (Leiden); $10^{7}$, Granada, $20 \mathrm{~km}$ ENE of Granáda, 1030 m, UTM: 30S VF3582, 23.vii.1986, C. Gielis (Leiden); 107, Granada, Sierra de Almijara, 9 km NW Otívar, 13.i.1988, leafmines on Bupleurum gibraltarium, e.l. 2-4.vi.1988, EvN no 88036, E.J. van Nieukerken (Leiden); 10", Granada, Sierra de Chapparal, $10 \mathrm{~km}$ W Lenteji, $900 \mathrm{~m}$, 39.ix.2004, G. Jeppesen (Copenhagen); 10 , Málaga, Istán, 1.vii.1994; 40", Málaga, Jimera de Líbar, 28.vi.1994; 220" 1o, ibidem, but 4.vii.2001; 40", ibidem, 4.vii.2001, larvae in leafmines on Bupleurum gibraltarium, e.l. vii.2001; 170 30 \% ibidem, but 27.vi.2002; 60" ibidem, but 27.vi.2003; 130", 2o, ibidem, but 23.vi.2005; 30", Málaga, Monda, 28.vi.2002, 30 $0^{7}$, ibidem, but 26.vi.2004, $10^{7}$, ibidem, but 23.vi.2006, all A. \& Z. Laštůvka (AL).

Other material. Leafmines from Serrania de Ronda, Uleila del Campo, Sierra de Grazalema, Cádiar, Otívar, Jimera de Líbar (AL, Leiden). In addition: Málaga, $2 \mathrm{~km} \mathrm{~W}$ Algatocín, $720 \mathrm{~m}$, UTM: $30 \mathrm{~S}$ TF9450, 19.i.1988, leafmines on Bupleurum gibraltarium, E.J. van Nieukerken (Leiden). 4 larvae from type locality, 29.ii.2000 (EvN2000048) and 7.i.2001 (EvN2001045), partly used for destructive DNA extraction.

\section{Diagnosis}

The moth resembles T. bupleurella of about the same size, the male is easily recognized by the extensive yellow androconial scaling on forewing underside and hindwing upperside. The male genitalia are unmis- takable by the peculiarly shaped valva and the enormous long and wide aedeagus. The female genitalia differ from other species of this group (especially from the similar $T$. bupleurella) by the remarkably small corpus bursae with indistinct signa, and the very long straight part plus ca 5 convolutions of the ductus spermathecae.

\section{Description}

Male (Figs 2, 3). Wingspan 5.0-5.6 mm, forewing length $2.3-2.5 \mathrm{~mm}$. Frontal tuft ferruginous. Scape white, sometimes with few scattered darker scales, flagellum brown; antenna with 34-40 segments. Thorax and forewing fuscous, distinct whitish ochreous tornal spot at two thirds. Cilia line distinct, terminal cilia silvery white. Forewing underside with distinct patch of dark yellow to amber androconial scales in basal third. Hindwing pale grey, basally widened, near frenulum with narrow patch of yellow to ferruginous androconial scales. Underside with velvet patch of androconial scales present. Legs ochreous grey. Abdomen pale fuscous, tufts on segments $6-8$ yellow.

Female. Wingspan $5.2-5.8 \mathrm{~mm}$, forewing length 2.3-2.5 mm, antenna with 32-35 segments. Further as male, but without special scales and with narrower hindwing.

Male genitalia (Figs 11, 17). Capsule length ca. 340$375 \mu \mathrm{m}$. Vinculum large, tapering, slightly concave to almost straight anteriorly. Tegumen with narrow rounded pseuduncus. Uncus with simple truncate apical process. Gnathos with large spatulate central element. Valva broad, $175-200 \mu \mathrm{m}$ long, without the usual apical finger-shaped process, but rounded apically and with a prominent pointed process medially on ventral margin. Aedeagus extremely large, ca. 670-740 $\mu \mathrm{m}$ long, twice as long as capsule, with two rows of small spines (not cornuti) near phallotrema, vesica with very long (ca $460 \mu \mathrm{m}$ ), thin and curved cornutus, with enlarged and recurved base.

Female genitalia (Figs 21, 27, 28). Total bursa length 590-600 $\mu \mathrm{m}$. Anal papillae broad, slightly prominent in the middle, with ca. 25 setae of medium length. T8 with groups of weak setae and scales laterally. S8 with two transversal rows of longer setae. Posterior apophyses slightly longer than anterior ones, thin. Corpus bursae remarkably small and poorly sclerotized, with pectinations, especially around signa; signa indistinct, not measurable. Ductus spermathecae very long, extending almost beyond bursa, with a long straight part 1.5 to 2 times as long as coiled part, the latter with 4.5-5.5 large convolutions. 

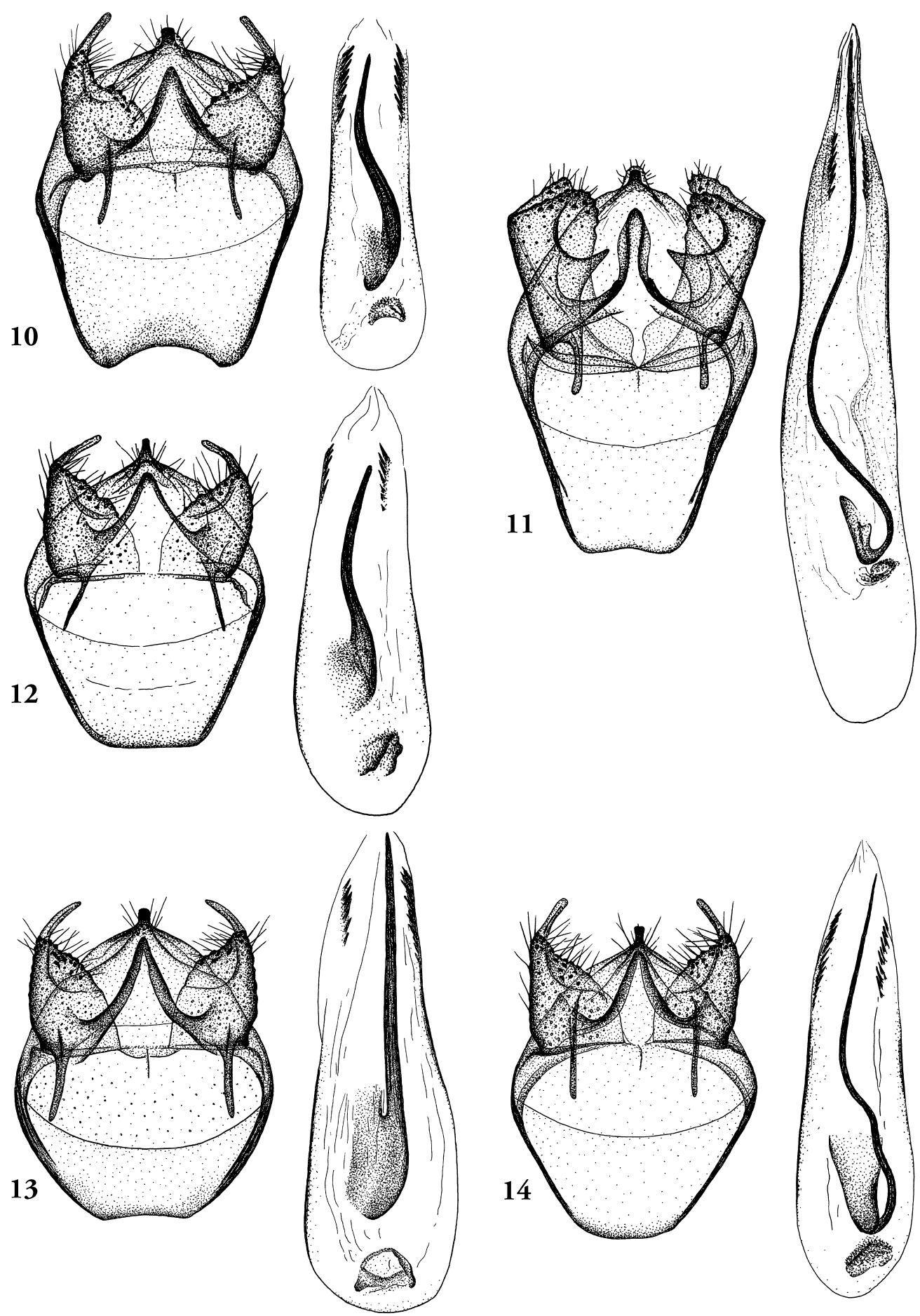

Figs 10-14. Trifurcula (Glaucolepis) species, male genitalia, ventral aspect. - 10, T. bupleurella, France, Aude, Sigean, e.l. iii.1999; 11, T. megaphallus, Paratype, Spain, Málaga, Jimera de Líbar, 4.vii.2001; 12, T. chretieni, Paratype, Spain, Santarém, Monsanto, 19.vi.2005; 13, T. siciliae, Holotype, Italy, Sicilia, Francavilla di Sicilia, e.l. vii.2000; 14, T. sanctibenedicti, Spain, Granada, Diezma, 28.vi.2004. 


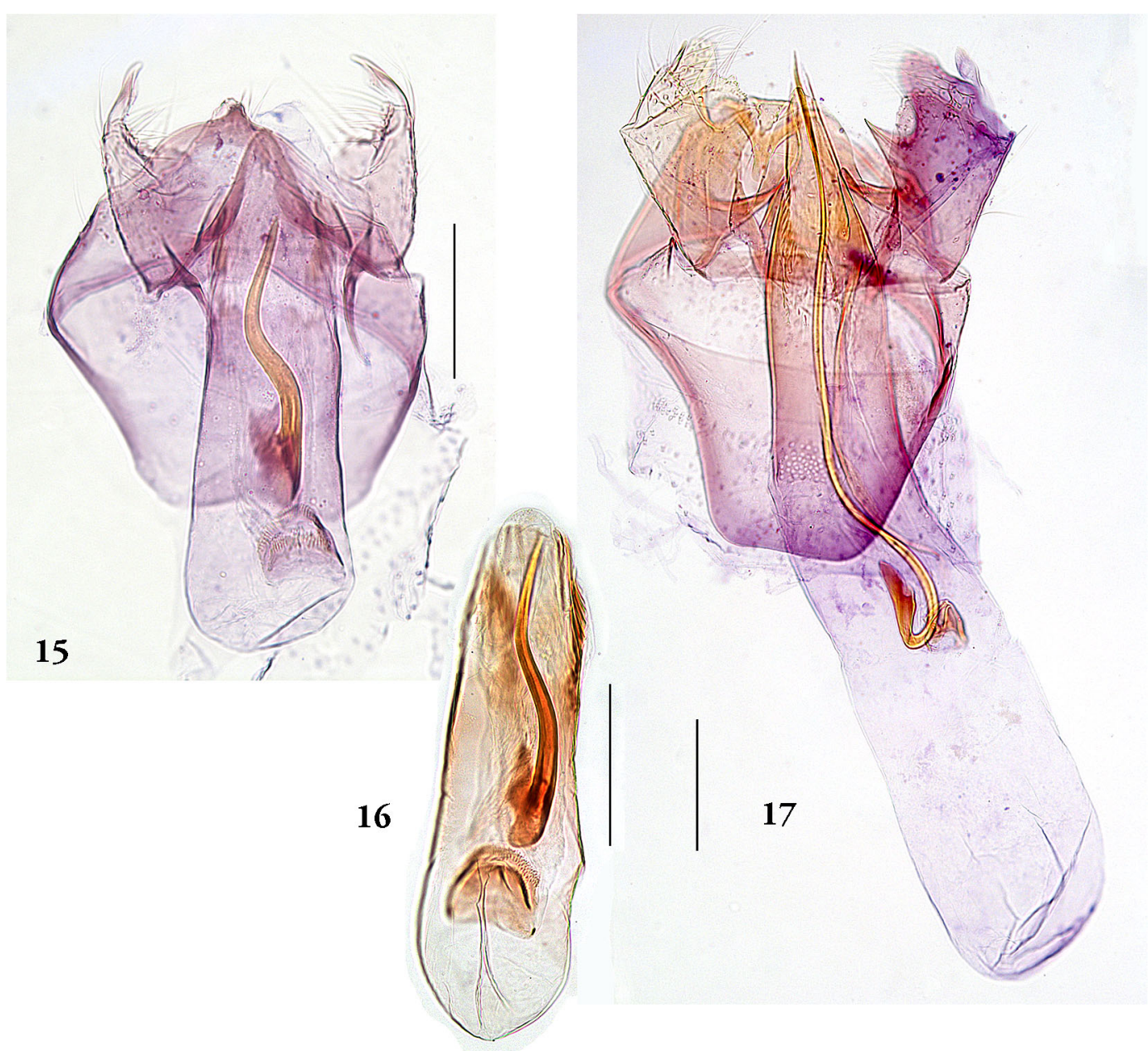

Figs 15-17. Trifurcula (Glaucolepis) species, male genitalia, ventral aspect. - 15, T. bupleurella, slide JCK15176, France; 16, T. bupleurella, aedeagus, slide JT081; 17, T. megaphallus, Holotype, slide JCK15168.

\section{Biology}

Hostplant. Bupleurum gibraltarium, a low evergreen shrub.

Egg and leafmine (Figs 34, 44, 45) either on upper or lower leaf surface. Leafmine a long and narrow gallery, with thin frass line, usually along one of the main veins. Larvae were found in January, February, June and July (but we did not search in other months), adults from larvae collected in June emerged very soon after collecting, without diapause. Adults collected from May to September, possibly with several generations annually.

\section{Distribution (Fig. 47)}

Southern Spain, Andalusia, in the Cordillera Baetica, limestone mountains, where the hostplant grows in relatively open and rocky sites, between 500 and $1150 \mathrm{~m}$ altitude.

\section{DNA barcodes}

Three DNA barcodes have been analysed, all from larvae from the type locality, the first two collected in 2000, the last in 2001 (RMNH.INS.11404, RMNH.INS.11405, RMNH.INS.11498) (BIN: BOLD:ACE2690).

\section{Etymology}

The specific name megaphallus, a noun in apposition, refers to the relative size of the aedeagus or phallus, unique within this genus. 


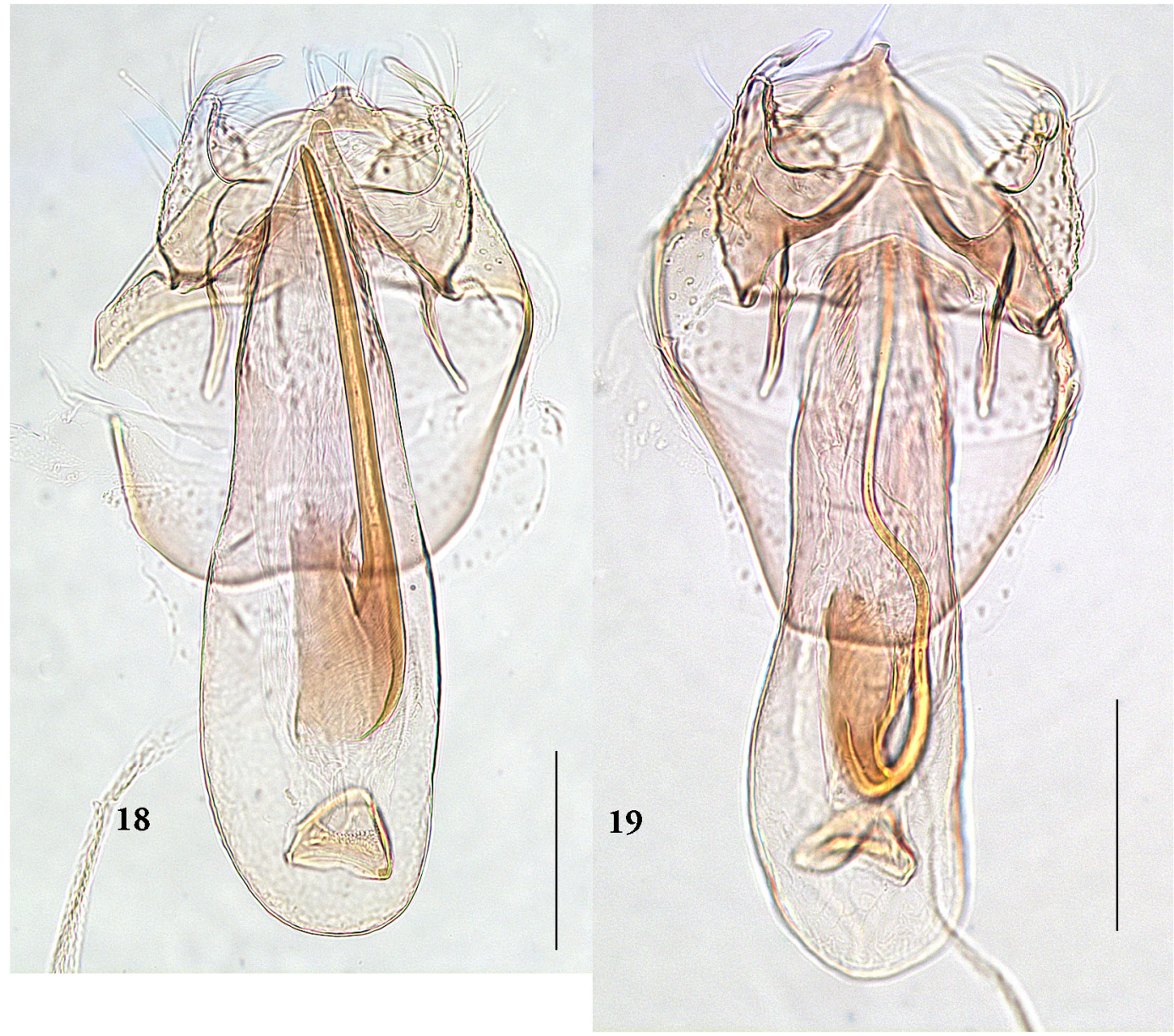

Figs 18, 19. Trifurcula (Glaucolepis) species, male genitalia, ventral aspect. - 18, T. siciliae, Paratype, slide EJvN1947, Italy, Sicilia; 19, T. sanctibenedicti, slide EJvN1927, Spain. Scales: $100 \mu \mathrm{m}$.

Trifurcula (Glaucolepis) chretieni Z. Laštůvka, A. Laštůvka \& van Nieukerken sp. n.

Figs 4, 5, 12, 22, 35-37, 40-43, 48

[Nepticula bupleurella Chrétien 1907: 91. Partim, only empty mines on Bupleurum rigidum. Misidentification].

Type material. Holotype $\sigma^{7}$. Spain, Barcelona, Santa Maria d'Oló, 25.vi.2009, leafmines on Bupleurum rigidum subsp. rigidum, e.l. vii.2009, A. \& Z. Laštůvka (AL).

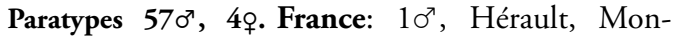
tagne de Gardiole, 133 m, UTM: 31T EJ587135, 5.vi.2011, leafmines on Bupleurum rigidum; garrigue on limestone, e.1. 1.vii.2011, EvN 2011063, E.J. van Nieukerken (Leiden). Spain: 10 , Albacete, El Pardal, 29.vi.2004; 10", Albacete, Reolid, 26.vi.2011; 30', 1o, Barcelona, Santa Maria d'Oló, 25.vi.2008, ibidem, 25.vi.2009, leafmines on Bu- pleurum rigidum subsp. rigidum, 1 e e.l. vii.2009; 10", Castellón, Cuevas de Vinromá, 26.vi.1991; 10", Cuenca, La Toba, 13.vi.2005; $1 \sigma^{\top}$, Málaga, Archidona, 13.vi.1993; 40, Málaga, Jimera de Líbar, 4.vi.2001, $8 \sigma^{\circ}$, ibidem, but 27.vi.2002, 7\%", ibidem, but 27.vi.2003, 60', ibidem, but 23.vi.2005, also always leafmines on $B$. rigidum subsp. paniculatum; 30', Sevilla, Coripe, 26.vi.2002, also leafmines on $B$. rigidum subsp. paniculatum; $1 \sigma^{7}$, Tarragona, 3 km S Fayón, 8.vi.2009; 10", Teruel, Montalbán, 16.vi.2002; 10", Toledo, Buenasbodas, 14.vi.2005.

Portugal: 20 $\sigma^{\top}$, Faro, Assumadas, 22.vi.2005, 10 $\sigma^{\top}$, 19, ibidem, but 21.vi.2006 and leafmines on $B$. rigidum subsp. paniculatum; $20^{\top}$, Santarém, Monsanto, 19.vi.2005 and leafmines on $B$. rigidum subsp. paniculatum, 1 + e.l. vii.2005; 30", Santarém, 

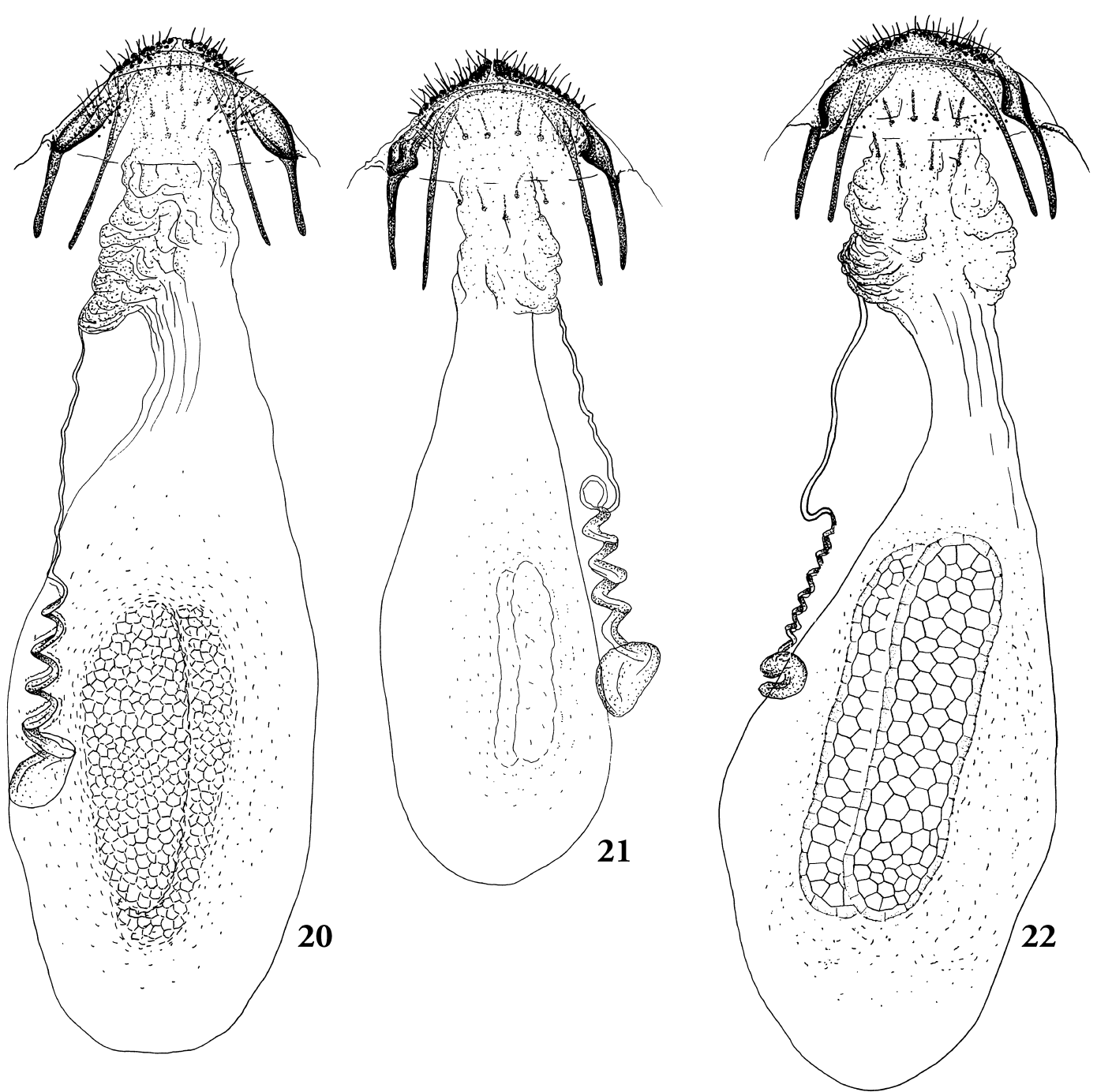

Figs 20-22. Trifurcula (Glaucolepis) species, female genitalia, dorsal aspect. - 20, T. bupleurella, France, Aude, Sigean, e.l. iii.1999; 21, T. megaphallus, Paratype, Spain, Málaga, Jimera de Líbar, 27.vi.2002; 22, T. chretieni, Paratype, Spain, Santarém, Valverde, e.l. vii.2005.

Valverde, 20.vi.2008, all A. \& Z. Laštůvka (all AL, some Leiden).

\section{Diagnosis}

The species resembles other Bupleurum feeding species with exception of $T$. sanctibenedicti, but is distinctly smaller. The male is recognised by the yellow androconial scales on forewing underside and hindwing upperside (both occasionally absent). The male genitalia differ from the very similar $T$. $b u$ pleurella especially by the long and wide aedeagus and by straight anterior margin of vinculum. The female genitalia are characterized by broad anal papil- lae, with smaller number of setae, by smaller, but more distinct signa in corpus bursae and by smaller convolutions on ductus spermathecae.

\section{Description}

Male (Figs 4, 5, 40, 41). Wingspan 4.0-4.6 mm, forewing length $1.8-2.1 \mathrm{~mm}$. Frontal tuft yellowish orange to ferruginous. Scape ochreous, flagellum brown; antenna with 28-37 segments. Thorax and forewing dark fuscous to black, lighter in the distal half of the hind margin, with a distinct whitish ochreous tornal spot at two thirds. Cilia line distinct, terminal cilia whitish. Forewing underside 

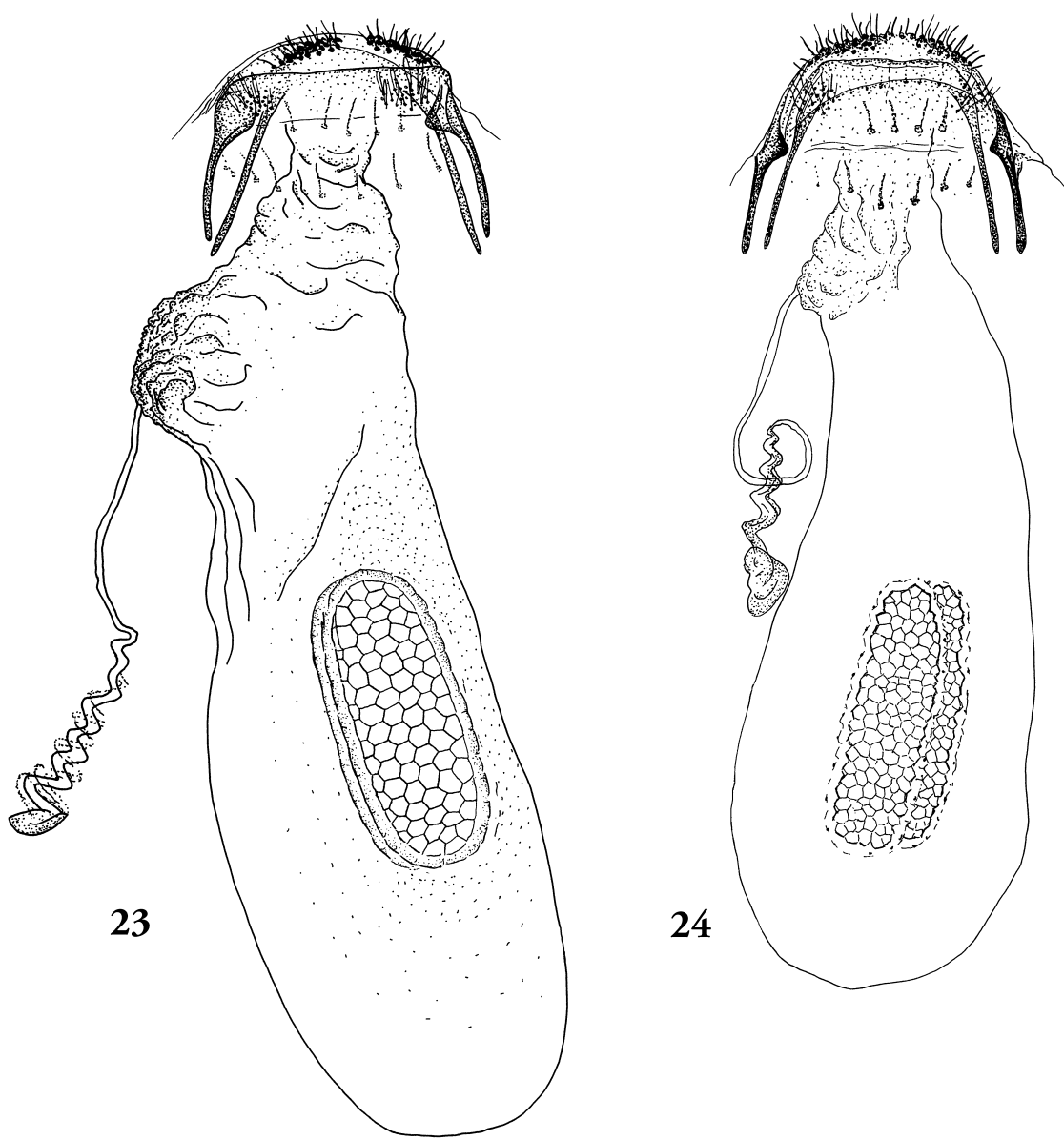

Figs 23, 24. Trifurcula (Glaucolepis) species, female genitalia, dorsal aspect. - 23, T. siciliae, Paratype, Italy, Sicilia, Francavilla di Sicilia, e.l. vii.2000; 24, T. sanctibenedicti, Spain, Granada, Puebla de Don Fadrique, 26.vi.2005.

usually with distinct patch of dark yellow to orange rusty androconial scales in basal third, which is smaller or are absent in some cases. Hindwing grey, basally widened, above near frenulum usually with a patch of yellow to rusty androconial scales which are absent occasionally. Underside with velvet patch of androconial scales. Cilia golden grey. Legs fuscous above and ochreous bellow. Abdomen fuscous, occasionally more ochreous ventrally, with short ochreous tufts on segments $6-8$.

Female. Wingspan $4.2-4.5 \mathrm{~mm}$, forewing length 1.9-2.2 mm. Antenna with 26-29 segments. Further as male, but without special scales and with narrower hindwing.

Male genitalia (Fig. 12). Capsule length ca $210 \mu \mathrm{m}$. Vinculum rounded or truncate anteriorly. Tegumen with slightly rounded triangular pseuduncus. Uncus with narrow triangular apical process. Gnathos with large, triangular central process. Valva trian- gular, inner margin slightly convex, apical digitate process long, curved inwards. Sublateral processes of transtilla long and thin. Aedeagus length ca $290 \mu \mathrm{m}$, about one-third longer than genital capsule, with two rows of ca 6-7 small spines near phallotrema, vesica with strong, slightly curved cornutus with enlarged base.

Female genitalia (Fig. 22). Total bursa length ca 750$780 \mu \mathrm{m}$. Anal papillae flat, broad, with approximately 20 short setae. T8 with groups of short setae and longer scales laterally. S8 with two irregular transversal rows of several longer setae. Posterior and anterior apophyses subequal, thin. Corpus bursae with pectinations, especially around signa. Signa distinct, about $200 \mu \mathrm{m}$ long, four or five times as long as wide, with $4-5$ rows of cells and with distinct margin. Ductus spermathecae with a long uncoiled part of same length as coiled part, the latter with approximately 5.5 convolutions. 

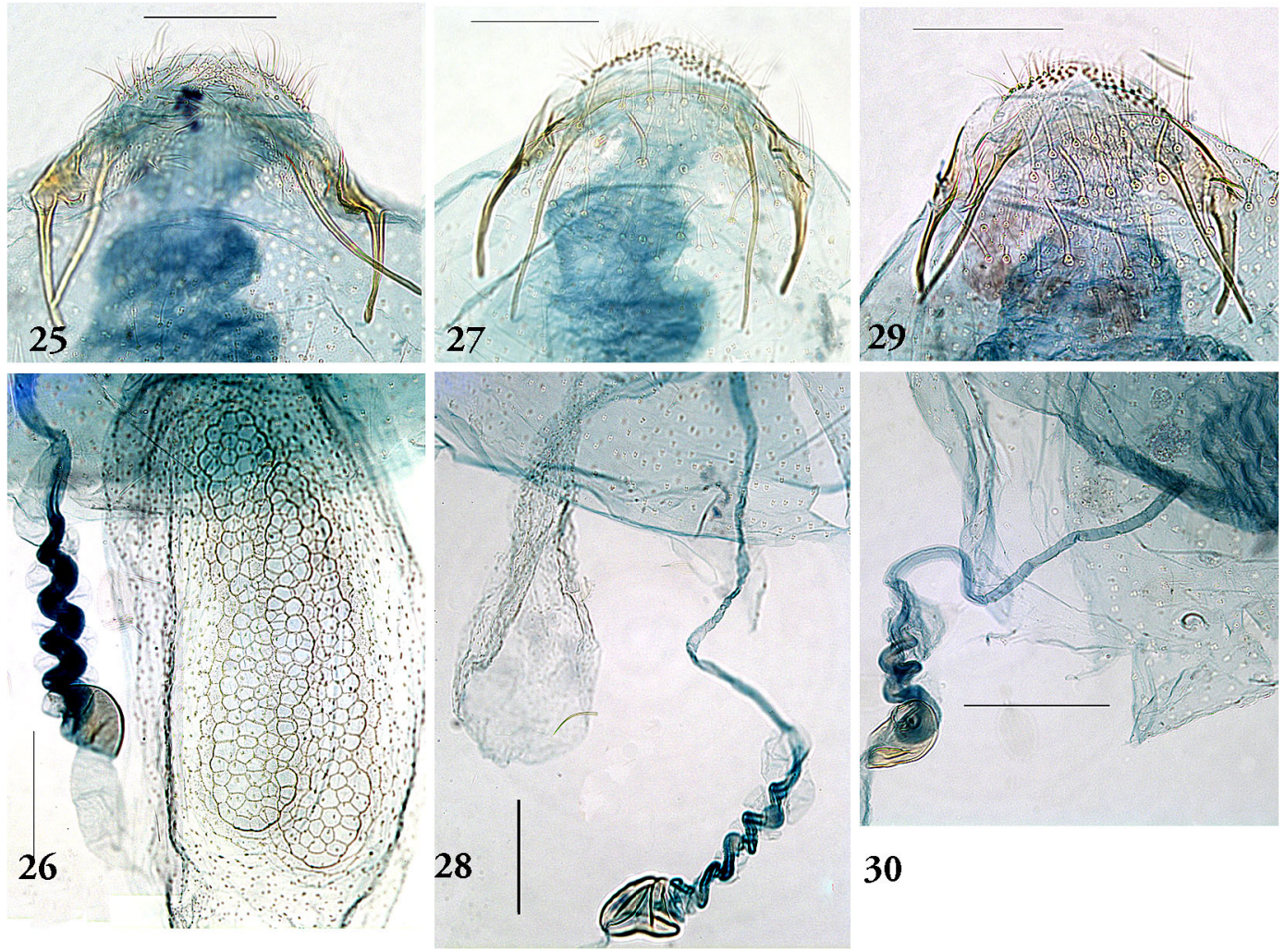

30

Figs 25-30. Trifurcula (Glaucolepis) species, female genitalia, terminal abdominal segments $(25,27,29)$ and details of ductus spermathecae and bursa $(26,28,30) .-25,26$, T. bupleurella, slides JCK1575 and JT080; 27, 28, T. megaphallus, Paratype, JCK15169; 29, 30, T. sanctibenedicti, slide JCK15172. Scales $100 \mu \mathrm{m}$.

\section{Biology}

Hostplant. Bupleurum rigidum (both $B$. rigidum subsp. rigidum and $B$. rigidum subsp. paniculatum), a perennial evergreen herb, often woody at base, usually on limestone.

Egg and leafmine (Figs 35-37, 42, 43) either on upper or lower leaf surface, or on the petiole or the green stem. Mine a long and thin gallery, with thin, sometimes interrupted frass line. The early part of the mine leads often along a main vein. Larvae and adults found in June and July, together with old, probably winter mines (not searched in other months); adults from collected larvae emerge soon, without diapause; probably in two or more generations annually.

\section{Distribution (Fig. 48)}

Southern France, Spain and Portugal, in garrigue or mattoral vegetations where the hostplant is common.

\section{DNA barcodes}

Three DNA barcodes have been analysed, all from the French locality, two larvae and one adult (RMNH.INS.18458, RMNH.INS.18462, RMNH. INS.24349).

\section{Etymology}

Named in honour of Pierre Chrétien (1846-1934), who discovered nepticulid mines on Bupleurum, including those on Bupleurum rigidum, and the first author to describe a number of Mediterranean species that are now placed in Trifurcula (Glaucolepis).

Trifurcula (Glaucolepis) siciliae Z. Laštůvka, A. Laštůvka \& van Nieukerken sp. $n$.

Figs 6, 7, 13, 18, 23, 33, 47

[Nepticula bupleurella: Klimesch 1975: 863; Karsholt et al. 1995: 7. Misidentification] 

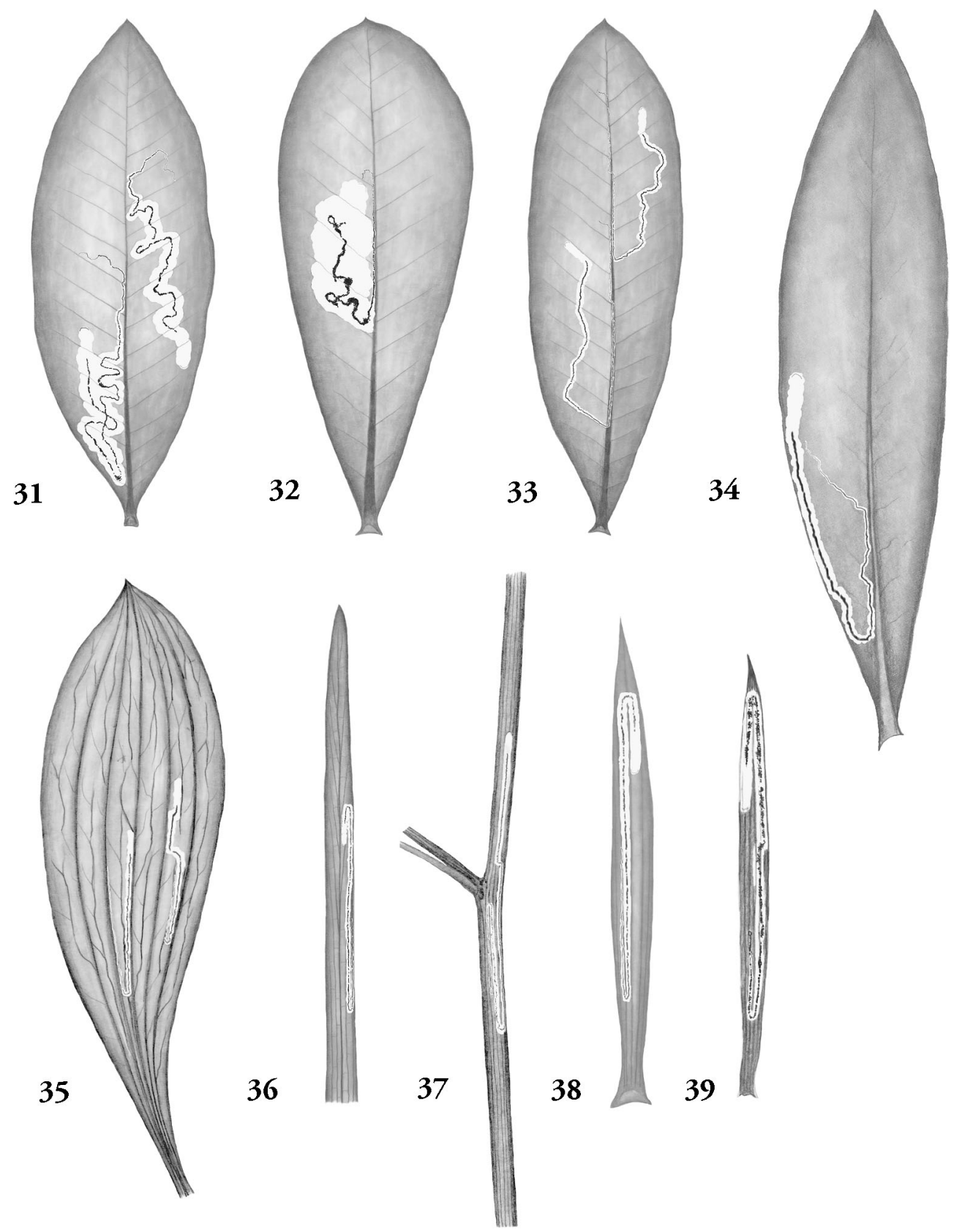

Figs 31-39. Trifurcula (Glaucolepis) species, leafmines on Bupleureum species. -31, T. bupleurella on B. fruticosum, France, Aude, Sigean, x.1998; 32, T. bupleurella on B. fruticosum, blotch mine, Spain, Granada, Cogollos, vii.2001; 33, T. siciliae on B. fruticosum, Italy, Sicilia, Francavilla di Sicilia, vi.2000; 34, T. megaphallus on B. gibraltarium, Spain, Málaga, Jimera de Líbar, 27.vi.2002; 35, T. chretieni on B. rigidum rigidum, Spain, Barcelona, Santa Maria d Oló, vi.2009; 36, 37, T. chretieni on B. rigidum paniculatum, resp. on leaf and stem, Spain, Santarém, Monsanto, vi.2005; 38, T. sanctibenedicti on B. fruticescens fruticescens, Spain, Teruel, Vivel del Rio, vii.1992; 39, T. sanctibenedicti on B. fruticescens spinosum, Spain, Granada, Diezma, vii. 1992. 

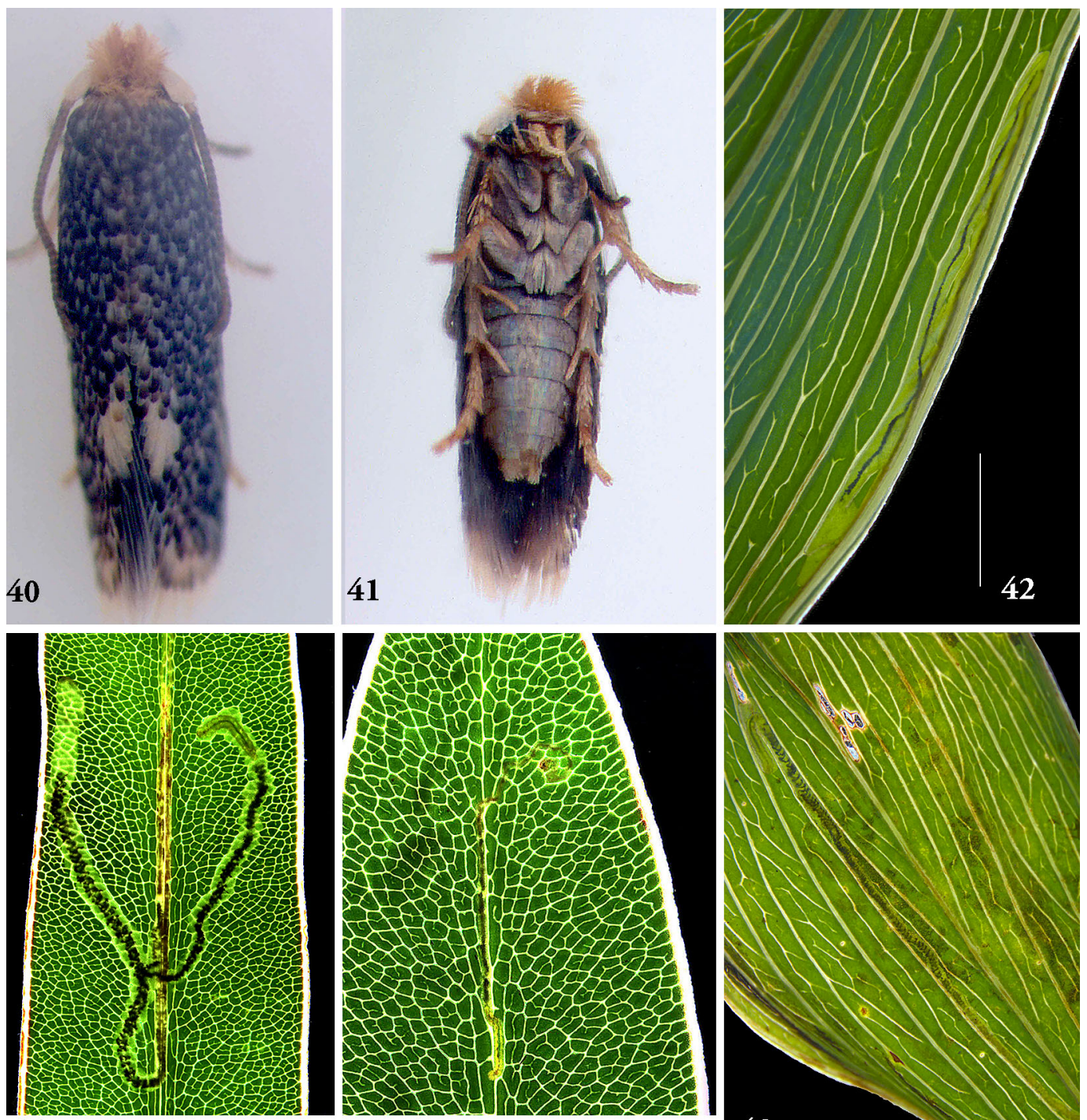
44 45

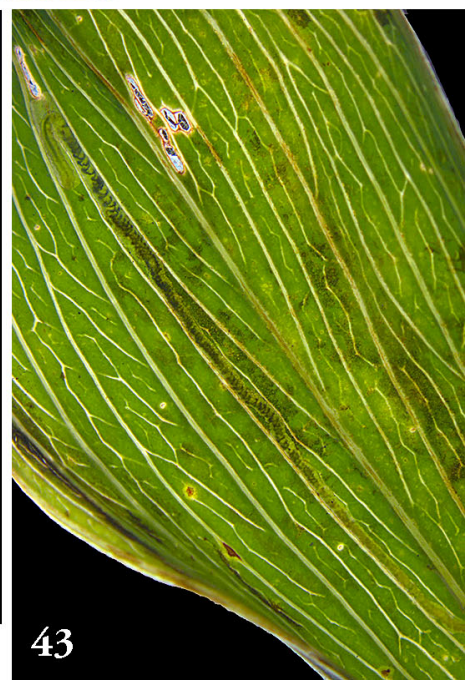

Figs 40-45. Trifurcula (Glaucolepis) species, biology. - 40-43, T. chretieni, France, EvN2011063, life male (40, 41), vacated mine on Bupleurum rigidum (42), larva in mine (43); 44, 45, T. megaphallus, larvae and leafmines on $B$. gibraltarium, EvN2001045.

Type material. Holotype $\sigma^{x}$. Italy, Sicilia, Francavilla di Sicilia, 23.vi.2000, leafmines on Bupleurum fruticosum, e.l. vii.2000, A. Laštůvka \& Z. Laštůvka (AL). Paratypes. $27 \sigma^{\prime \prime}, 19$ ㅇ․ Italy, Sicilia: $5 \sigma^{\prime \prime}, 1 \%$, Catania, Taormina, 19.xii.1949, mines on Bupleurum fruticosum, Zucht 684, e.l. 28.iii.-12.v.1950, J. Klimesch (Munich, Leiden); 30 , [Messina, Taormina], no. 89, no. $583\left(20^{7}\right)$, leg. Groschke (Stuttgart); 60, $2 \circ$, Francavilla di Sicilia, 18.vi.1995, 30 30 , 3oidem, but 14.vi.2000, same locality, but 23.vi.2000, leafmines on Bupleurum fruticosum, 100 13 , 13, e.l. vii.2000, all A. \& Z. Laštůvka (AL, Leiden).

\section{Diagnosis}

Externally very similar to other species of this group, especially to T. bupleurella. It differs by the distinct groups of rusty androconial scales on the forewing underside and hindwing upperside. The male genitalia are recognizable by the large aedeagus with the straight cornutus and by the anteriorly only slightly 

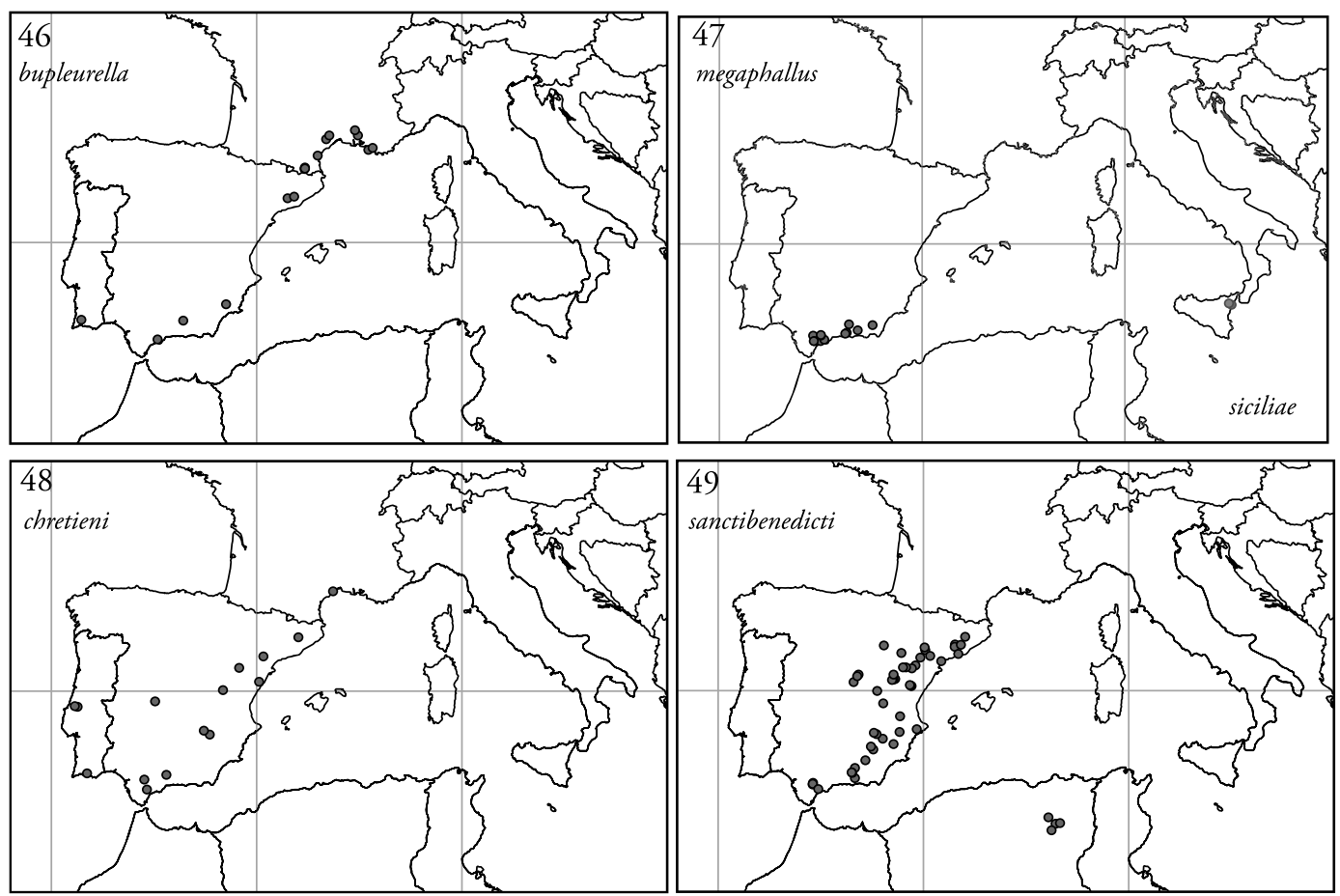

Figs 46-49. Trifurcula (Glaucolepis) species, distribution. - 46, T. bupleurella; 47, T. megaphallus (Spain) and T. siciliae (Sicily); 48, T. chretieni; 49, T. sanctibenedicti.

concave or nearly straight vinculum. The female genitalia are characterized by distinct elongate signa and by greater number of smaller convolutions on ductus spermathecae compared to the other species.

\section{Description}

Male (Figs 6, 7). Wingspan 4.8-5.0 mm, forewing length $2.3-2.4 \mathrm{~mm}$. Frontal tuft orange to ferruginous. Scape ochreous, with an orange tinge, flagellum fuscous; antenna with 32-38 segments. Thorax and forewing dark brown to black, lighter along the hind margin, with a distinct whitish ochreous tornal spot at two thirds. Cilia line distinct, cilia greyish with an ochreous tinge, ochreous in the forewing apex. Forewing underside brown with a large patch of brownish rusty androconial scales. Hindwing grey, basally widened, above near frenulum with a large patch of rusty androconial scales. Underside with velvet patch of androconial scales. Legs pale ochreous fuscous. Abdomen ochreous brownish, ochreous ventrally, with short ochreous tufts on segments 6-8. Female. Wingspan $4.8-5.2 \mathrm{~mm}$, forewing length 2.3-2.4 mm. Antenna with 30-33 segments. Further as male, but without special scales and with narrower hindwing.
Male genitalia (Figs 13, 18). Capsule length 240$260 \mu \mathrm{m}$. Vinculum broad, slightly concave or nearly straight anteriorly. Tegumen with rounded triangular pseuduncus. Uncus with slightly truncate and relatively long apical process. Gnathos with large, triangular, pointed central element. Valva triangular, $115 \mu \mathrm{m}$ long, inner margin slightly convex, apical digitate process long, slightly curved inwards; sublateral processes long. Aedeagus 380-405 mm long, about 1.5 as long as capsule, with two rows of ca 10 small spines near phallotrema, vesica with large, straight cornutus (300 $\mu \mathrm{m}$ long) with enlarged and recurved base.

Female genitalia (Fig. 23). Total length of bursa 900 $1080 \mu \mathrm{m}$. Anal papillae rounded, broad, with groups of approximately 40 short setae. T8 with groups of very short setae and scales laterally. S8 with two transversal rows of longer setae. Posterior and anterior apophyses subequal, thin. Corpus bursae with pectinations, especially around signa. Signa distinct, about $360 \mu \mathrm{m}$ long, five to six times as long as wide, 4-5 rows of cells wide and with a distinct margin. Ductus spermathecae with a long uncoiled part slightly longer than coiled part, the latter with approximately 6-7 narrow convolutions. 


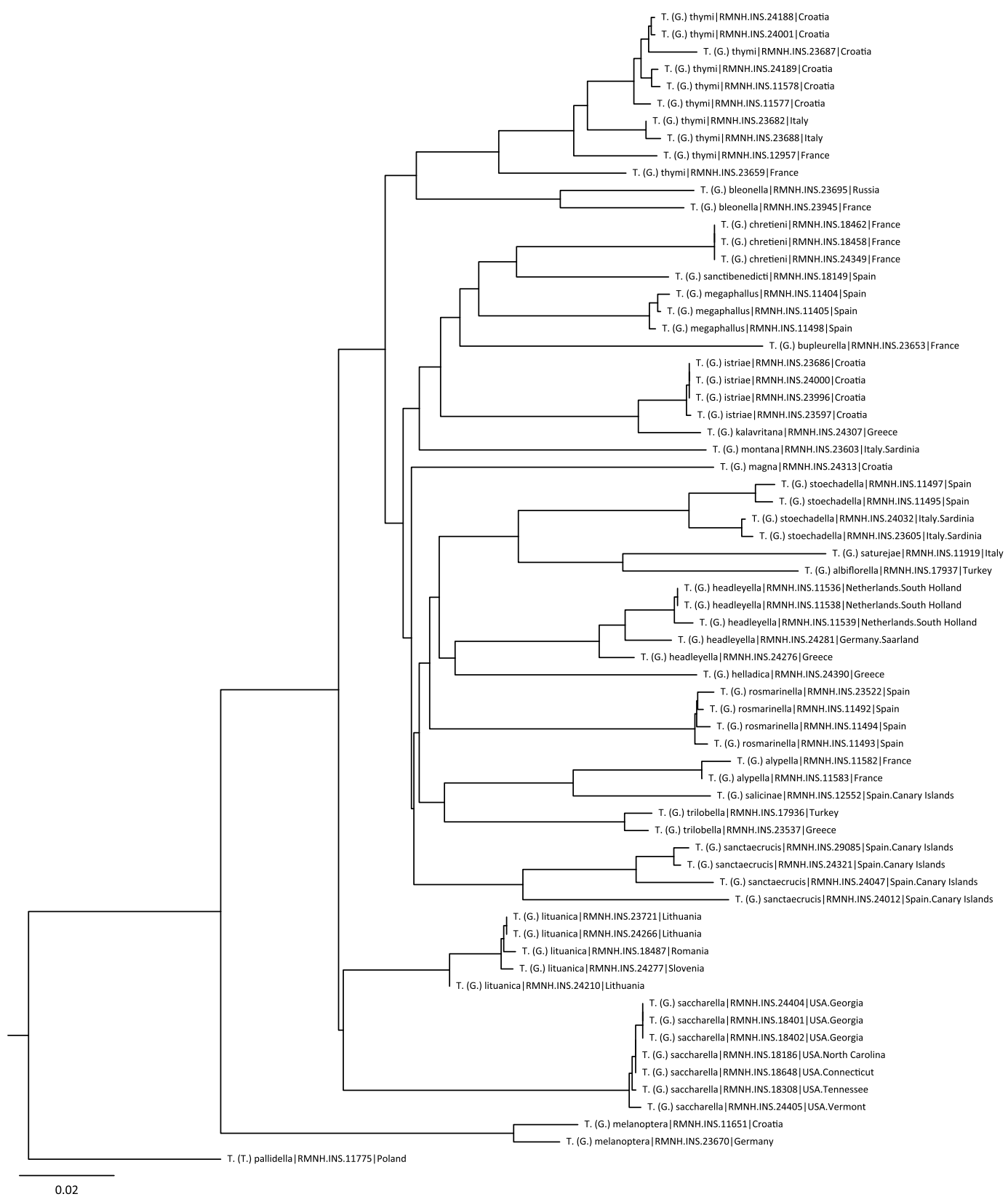

Fig. 50. Neighbor Joining tree of DNA barcodes.

\section{Biology}

Hostplant. Bupleurum fruticosum, an evergreen shrub. Egg either on upper or lower leaf surface, most frequently near one of the main veins.

Leafmine (Fig. 33) a very long and narrow gallery, with a thin central frass line, always on leaf upper- side. The early part of the mine often runs along or near a main vein. Larvae found in December and June (not searched in other months) and adults collected in June which should be the first generation, next generation emerged in July; in two or more generations annually. 


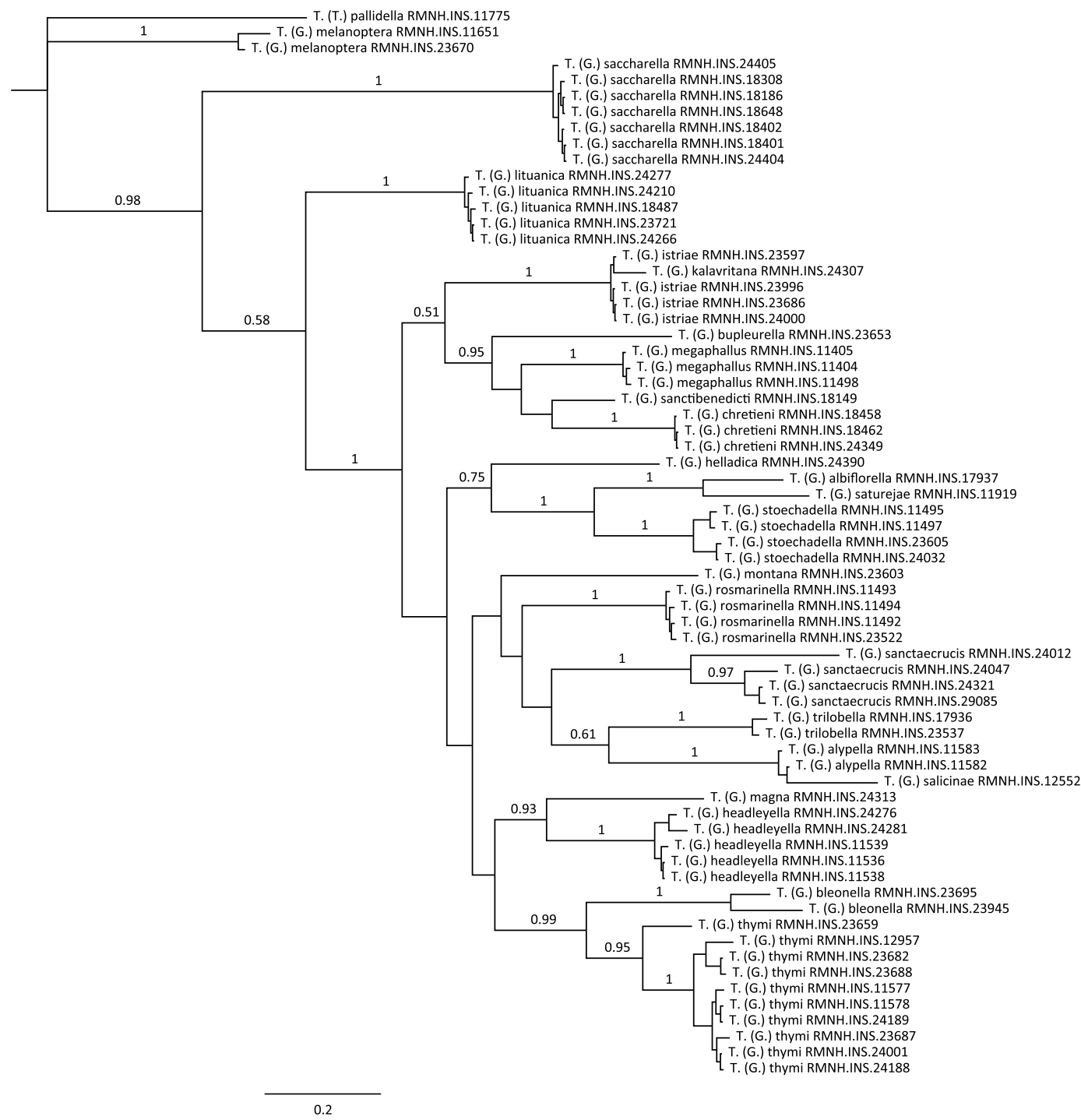

Fig. 51. Strict consensus tree of Bayesian analysis of DNA barcodes. Posterior probabilities given when higher than 0.50 .

\section{Distribution (Fig. 47)}

Sicily. The species inhabits various places where its hostplant occurs, such as roadsides, pastures and rocks.

\section{Etymology}

The species name, "siciliae", a noun in genitive case, is derived from the island where this species occurs ("of Sicily").

\section{Remarks}

The specimens from the Groschke collection in Stuttgart, which only have a number as label, are assumed to belong to the series of moths that Groschke collected during the war in Taormina (Groschke 1944). See the explanation for the holotype of $E c$ toedemia caradjai (Groschke, 1944) (van Nieukerken 1985), the number ' 583 ' on two studied males, is just outside the range discussed in that paper as being Taormina material. The number ' 89 ' cannot easily be explained, for now the specimens is considered to be also from Taormina. The material collected 
by Klimesch was earlier reported as T. bupleurella (Karsholt et al. 1995).

\section{Trifurcula (Glaucolepis) sanctibenedicti Klimesch}

Figs 8, 9, 14, 19, 24, 29, 30, 38, 39, 49

Trifurcula (Fedalmia) sanctibenedicti Klimesch 1979: 24. Holotype $\sigma^{7}$, Spain: "Hispania, Montserrat, 800-900 m, ex 1. VII.1977, Zucht 1156, Bupleurum fruticescens 10.IX. 1976". ZSM [paratypes examined]

Trifurcula (Glaucolepis) sanctibenedicti van Nieukerken 1986: 15 [checklist]; van Nieukerken et al. 2004: 231 [distribution Spain]

\section{Diagnosis}

The inclusion of Trifurcula sanctibenedicti in this species group is evident from its male and female genitalia morphology, but it clearly differs by the ochreous ground colouration from other species. This pale colouration is similar to several other Trifurcula species, but the fields of androconial scales on the forewing underside and on hindwing upperside are quite characteristic. The male genitalia are recognizable among the group especially by the large aedeagus with very long and thin cornutus and by slightly convex vinculum anteriorly. The female genitalia are characterized by broad anal papillae with many short setae and by distinct long signa in corpus bursae.

\section{Description}

Male (Figs 8, 9). Wingspan $5.0-5.5 \mathrm{~mm}$, forewing length $2.3-2.6 \mathrm{~mm}$. Frontal tuft ferruginous. Scape pale ochreous, flagellum fuscous; antenna with 3537 segments. Thorax brown, forewing covered with sparse brown scales and ochreous ground colouration is visible, apex and hind margin lighter. Cilia line distinct, cilia ochreous greyish. Forewing underside brown with different sized patch of pale ochreous yellow to rusty androconial scales. This patch is absent or very small in specimens reared from Bupleurum fruticescens subsp. spinosum, sometimes also from $B$. fruticescens subsp. fruticescens. Hindwing basally widened, pale greyish, above near frenulum with a patch of ochreous yellow to pale rusty androconial scales. Underside with velvet patch of androconial scales. Legs pale ochreous fuscous. Abdomen ochreous brownish, ochreous ventrally, with short ochreous tufts on segments 6-8.

Female. Wingspan 5.1-5.6 mm, forewing length 2.4-2.6 mm. Antenna with 33-34 segments. Further as male, but without special scales and with narrower hindwing.
Male genitalia (Figs 14, 19). Capsule length 245$260 \mathrm{~mm}$. Vinculum broad, nearly straight or slightly convex anteriorly. Tegumen with narrow rounded triangular pseuduncus. Uncus with narrow and relatively long apical process. Gnathos with large, triangular central element. Valva triangular, 110-120 $\mu \mathrm{m}$ long, apical digitate process long, curved inwards; sublateral processes long. Aedeagus length 325$370 \mu \mathrm{m}$, about 1.5 as long as capsule, with two rows of ca 7-12 small spines near phallotrema; vesica with a 240-265 $\mu \mathrm{m}$ long, thin curved cornutus with distinctly enlarged and recurved base.

Female genitalia (Figs 24, 29, 30). Total length of bursa 785-1000 $\mu \mathrm{m}$. Anal papillae rounded, broad, with groups of approximately 25 short setae. T8 with groups of very short setae and scales laterally. Corpus bursae with pectinations, especially around signa. Signa distinct, about 245-270 $\mu \mathrm{m}$ long, 3-4 times as long as wide, $5-6$ rows of cells wide. Ductus spermathecae with 3.5-4.5 large convolutions.

\section{Biology}

Hostplant. Bupleurum fruticescens subsp. fruticescens, a small evergreen shrub and $B$. fruticescens subsp. spinosum, a very spiny evergreen "hedgehog" shrub of high mountains.

Egg and leafmine on lower side of a leaf. Leafmine (Figs 38, 39) a very long and narrow gallery, with a thin central frass line. Larvae found in September and from January to July, but less often in June and July; adults from June to August, adults from larvae collected in June emerge without diapause, the same time as larvae collected in earlier months; in one or possibly two generations annually.

\section{Distribution (Fig. 49)}

Eastern and southern Spain, in limestone mountains in garrigue and maquis vegetations on $\mathrm{Bu}$ pleurum fruticescens subsp. fruticescens, usually below $1000 \mathrm{~m}$, but occasionally up to $1250 \mathrm{~m}$. In southern Spain and Algeria on higher mountains where $B u$ pleurum fruticescens subsp. spinosum grows in mountain and alpine shrub (the so-called hedgehog zone) and Cedar forests (Aurès mountains). To be expected in Morocco.

\section{DNA barcodes}

One DNA barcode has been analysed, from a larva from the type locality Montserrat, collected in 2010 (RMNH.INS.18149, Genbank accession number JX261918). (BIN BOLD:ABW9597)

\section{Remarks}

The populations in higher mountains in the "hedgehog" vegetation zone on $B$. fruticescens subsp. spino- 
sum often differ from lower populations in absence or reduction of the androconial patch, but since this character is variable, and other differences are absent we consider these populations as conspecific. Detailed molecular studies are needed to evaluate the relationship of these populations. We have not yet seen any adults from the Algerian populations, these records are entirely based on larvae and leafmines.

Additional material. Algeria: leafmines and larvae, all on Bupleurum fruticescens subsp. spinosum, Aurès mts, $30 \mathrm{~km}$ SSE Batna, $1700 \mathrm{~m}$, 2.v.1980, EvN 80073; Aurès, N. of Djebel Chélia, 1400 m, 4.v.1980, EvN80079; Belezma mts, 14 km WNW Batna, 1700 m, 1.v.1980, EvN 80071; Gorges de Tighanimine, $45 \mathrm{~km} \mathrm{~S}$ Batna, $900 \mathrm{~m}$, 3.v.1980, EvN 80078, all leg. E.J. van Nieukerken \& G. Bryan (Leiden). Spain: 70", 1क, Albacete, El Pardal, 22.vi.2009; 50" Albacete, Las Espineras del León, 25.vi.2011, 60', same locality, but 23.vi.2012, A. \& Z. Laštůvka (AL); 20" Barcelona, Anoia, Jorba, 12.viii.2006, E. Requena; 10", Barcelona, Anoia, Mirales, 11.viii.2006, E. Requena (Leiden); larvae, Barcelona, Montserrat, N. slope above Monasterio, 2.v.2010, leafmines on Bupleurum fruticescens subsp. fruticescens, E.J. van Nieukerken (Leiden); 307, Barcelona, Santa Maria d'Olo, 25.vi.2008, A. \& Z. Laštůvka (AL); leafmines, Cádiz, Sierra de Grazalema, Puerto de 1. Palomas, $4 \mathrm{~km} \mathrm{NW}$ Grazalema, 1370 m, 27.ii.2000, EvN2000036, bare mountain slopes, limestone; on Bupleurum fruticescens subsp. spinosum, E.J. van Nieukerken \& S. Richter; $20^{7}, 2 \circ$, Cádiz, Sierra del Endrinal, $2.5 \mathrm{~km} \mathrm{SW} \mathrm{Grazalema,}$ $1200 \mathrm{~m}, 28 . i i .2000$, W slopes limestone mountains, leafmines on Bupleurum fruticescens subsp. spinosum, EvN 2000044, e.l. 7-20.vi.2000, E.J. van Nieukerken (Leiden); 20", Cuenca, Boniches, 13.vi.2007; $10^{x}$, 1\%, Granada, Puebla de Don Fadrique, La Sagra, 21.vi.2009; 10" Granada, Puebla de Don Fadrique, Nablanca, 22.vi.2012, A. \& Z. Laštůvka (AL); 1o, Granada, Sierra Nevada, S slopes, $8 \mathrm{~km}$ SW Treveléz, $1900 \mathrm{~m}, 11.1 .1988$, leafmines on $\mathrm{Bu}$ pleurum fruticescens subsp. spinosum, EvN 88029, e.l. 12.v.1988, E.J. van Nieukerken (Leiden); 10", 1\%, Granada, Sierra Nevada, Veleta-road, $5 \mathrm{~km}$ S Guejar, $1900 \mathrm{~m}, 12 . \mathrm{i} .1988$, leafmines on $\mathrm{Bu}$ pleurum fruticescens subsp. spinosum, EvN 88033, e.l. 20.v-13.vi.1988, E.J. van Nieukerken (Leiden); 20', Granada, Zujar, Jabalcon, 20.vi.2009; 10". Huesca, Candasnos, 6.vi.2010; Soria, Puerto de la Bigornia, 12.vi.2012, leafmines on Bupleurum fruticescens subsp. fruticescens; $10^{7}, 1 \%$, Tarragona, Fayón, 8.vi.2009; 30", Teruel, Albarracín, Veldevecar, 25.vi.2012; 10", Teruel, Ejulve, 29.vi.2005; 70", Teruel, Pozondón, 12.vi.2007, 907 , same locality, but 24.vi.2008; 50", 19, Zaragoza, Tosos, 12.vi.2006, A. \& Z. Laštůvka (AL).

\section{DNA barcoding}

We add here the DNA barcodes of two of the new species, T. megaphallus and T. chretieni, to those already known and published (Ivinskis et al. 2012) and include a few new DNA barcodes of other species in the subgenus. In Fig. 50 we present the extended Neighbor Joining tree based on that publication and our new barcodes. All four Bupleurum feeding species are clearly separated with interspecific distances between $7.4 \%$ and $11.8 \%$. The Bayesian analysis resulted in a relatively well supported strict consensus tree (Fig. 51), see discussion below.

\section{Hostplant relationships and phylogeny}

The genus Bupleurum takes a rather isolated position in Apiaceae, both molecularly and morphologically because of its entire leaves (usually pinnate in other Apiaceae) and the presence of several woody species (Neves \& Watson 2004), whereas the large majority of Apiaceae are herbs. The genus is widespread in the northern hemisphere, with ca. 150 species, with its highest diversity in the Mediterranean region (Neves \& Watson 2004). Most of the species on which Trifurcula species occur, except B. fruticescens, were found in a molecular study to form a small clade, sister to all remaining species (Neves \& Watson 2004). These authors erected the subgenus Penninervia S.S. Neves \& M.F. Watson for this clade, with type species $B$. fruticosum. Most host species are restricted to the western Mediterranean region, only $B$. fruticosum is more widespread and also occurs in the eastern Mediterranean. However, despite searching e.g. in Greece, we have never seen nepticulid leafmines on this or other Bupleurum species outside the relatively small distribution area of the Trifurcula species studied here. Our tentative phylogenetic analysis, based on DNA barcodes (Fig. 51), suggests that the sistergroup may have been feeding on either Globularia (Plantaginaceae) or Lamiaceae. Almost all hostplants of the Mediterranean clade of Glaucolepis belong to the asteroid clade of the angiosperms (APG III 2009), with Lamiaceae and Plantaginaceae in the order Lamiales of the lamiid clade and Apiaceae in the order Apiales of the campanulid clade, to which also the Asteraceae belong (genus Launaea, host for T. zollikofferiella (Chrétien, 1914)). The only exception is T. bleonella (Chrétien, 1904) that feeds on Linaceae in the Malpighiales in the fabid clade. The tentative phylogeny suggests that T. melanoptera van Nieukerken \& Puplesis, 1991 (and thus the T. raikhonae group) forms a polytomy with the outgroup and the remaining Glaucolepis; the species in this group are thought to be 
gall makers on Rosaceae (van Nieukerken \& Puplesis 1991). The following branch is the North American T. saccharella (Braun, 1912), feeding on Acer (Sapindaceae, Sapindales, malvids), sister to the Mediterranean clade. Since species feeding on Lamiaceae occur throughout the Mediterranean clade, the possible scenario is that during the drying climate of the Tertiary, the ancestor shifted from tree feeding to feeding on Lamiaceae shrubs. Shifts to the other families are probably all secondary shifts from Lamiaceae feeding ancestors.

\section{Acknowledgements}

We would like to acknowledge the following persons for sending specimens on loan: Ole Karsholt (Copenhagen, Denmark), Emili Requeña (Anoia, Spain), Andreas Segerer (Munich, Germany), to Antonio Vives (Madrid, Spain) for support in obtaining collecting permits for Spain, to Louis Silva (ICN, Lisboa) for the permit to collect Lepidoptera in protected areas of Portugal.

Sjaak Koster (Naturalis) is acknowledged for preparing many genitalia slides and Camiel Doorenweerd and Suzanne van der Hoeven (Naturalis) are acknowledged for assistance with molecular work.

\section{References}

APG III, 2009. An update of the Angiosperm Phylogeny Group classification for the orders and families of flowering plants: APG III. - Botanical Journal of the Linnean Society 161(2): 105-121. DOI:10.1111/j.10958339.2009.00996.x.

Chrétien, P., 1907. Les chenilles des Buplèvres. - Naturaliste. Paris 29(483): 89-91.

Ellis, W.N., 2013. Leafminers and Plant galls of Europe. Bladmineerders en plantengallen van Europa. - http:// www.bladmineerders.nl/index.htm.

Groschke, F., 1944. Neues über Minierer aus dem Mittelmeergebiet. - Mitteilungen der Münchner Entomologischen Gesellschaft 34: 115-124.

Hand, R., 2011. Apiaceae. - In: The Euro+Med PlantBase - the information resource for EuroMediterranean plant diversity. Botanic Garden and Botanical Museum Berlin-Dahlem. http://ww2.bgbm. org/EuroPlusMed/.

Ivinskis, P., E.J. van Nieukerken \& J. Rimsaite, 2012. Trifurcula (Glaucolepis) lituanica sp. n., an unexpected new stem-miner on Salvia pratensis occurring in eastern Europe (Lepidoptera: Nepticulidae). - Zootaxa 3570: 41-55.

Karsholt, O., E.J. van Nieukerken, S.E. Whitebread \& S. Zangheri, 1995. Lepidoptera Zeugloptera, Dacnonypha, Exoporia, Monotrysia (= Micropterigoidea, Eriocranioidea, Hepialoidea, Nepticuloidea, Incurvarioidea, Tischerioidea). - Checklist delle Specie della
Fauna Italiana 80: 1-12. http://www.faunaitalia.it/ checklist/introduction.html.

Klimesch, J., 1975. Ergebnisse von Untersuchungen einiger Nepticuliden-Typen der Sammlung des Muséum national d'Histoire naturelle, Paris (Lep., Nepticulidae). - Bulletin du Muséum National d'Histoire Naturelle. 3e Série, Zoologie 221(314): 861-866.

Klimesch, J., 1976. Zur Genitalmorphologie und Lebensweise der Fedalmia (Stigmella) saturejae (Parenti, 1963) (Lep., Nepticulidae). - Zeitschrift der Arbeitsgemeinschaft Österreichischer Entomologen 28(1-3): 45-48.

Klimesch, J., 1977. Beiträge zur Kenntnis der Microlepidopteren-Fauna des Kanarischen Archipels. 1. Beitrag: Nepticulidae, Tischeriidae. - Vieraea 6: 191-218.

Klimesch, J., 1979. Beiträge zur Kenntnis der Nepticuliden. Beschreibung zweier neuer Arten (Stigmella abaiella n. sp. und Trifurcula (Fedalmia) sanctibenedicti n. sp.) (Lepidoptera, Monotrysia). - Zeitschrift der Arbeitsgemeinschaft Österreichischer Entomologen 31(12): 21-27.

Knölke, S., S. Erlacher, A. Hausmann, M.A. Miller \& A.H. Segerer, 2005. A procedure for combined genitalia dissection and DNA extraction in Lepidoptera. - Insect Systematics and Evolution 35(4): 401-409. DOI:10.1163/187631204788912463.

Laštůvka, A. \& Z. Laštůvka, 1997. Nepticulidae Mitteleuropas. Ein illustrierter Begleiter (Lepidoptera). - Konvoj, Brno. 229 pp.

Laštůvka, A. \& Z. Laštůvka, 2000. Zwei neue Globularia minierende Trifurcula-Arten (Lepidoptera, Nepticulidae). - Acta Musei Moraviae, Scientiae biologicae 85: 289-296.

Laštůvka, A. \& Z. Laštůvka, 2011. New records of Nepticulidae and Gracillariidae from the Iberian Peninsula (Insecta: Lepidoptera). - SHILAP Revista de Lepidopterologia 39(156): 379-387.

Laštůvka, Z. \& A. Laštůvka, 1998. Beitrag zur Kenntnis der Nepticulidenfauna Griechenlands (Lepidoptera, Nepticulidae). - Stapfia 55: 313-326. http://www. landesmuseum.at/datenbanken/digilit/?litnr=56.

Laštůvka, Z. \& A. Laštůvka, 2007. Seven new species of the subgenus Glaucolepis Braun from southern Europe (Lepidoptera: Nepticulidae, Trifurcula). - Acta Universitatis Agriculturae et Silviculturae Mendelianae Brunensis 55(5): 101-110. http://science.naturalis.nl/ media/61401/lastuvkaza2007glaucolepis.pdf.

Morton, A., 2000. DMAP for Windows, 7.0e. - Alan Morton, Winkfield, Windsor, Berkshire. http://www. dmap.co.uk/welcome.htm.

Neves, S.S. \& M.F. Watson, 2004. Phylogenetic relationships in Bupleurum (Apiaceae) based on Nuclear Ribosomal DNA ITS sequence data. - Annals of Botany 93(4): 379-398. DOI:10.1093/aob/mch052.

Nieukerken, E.J. van, 1985. A taxonomic revision of the western Palaearctic species of the subgenera Zimmermannia Hering and Ectoedemia Busck s. str. (Lepi- 
doptera, Nepticulidae), with notes on their phylogeny. - Tijdschrift voor Entomologie 128(1): 1-164. http:// biostor.org/reference/61076.

Nieukerken, E.J. van, 1986. A provisional phylogenetic check-list of the western Palaearctic Nepticulidae, with data on hostplants (Lepidoptera). - Entomologica Scandinavica 17(1): 1-27. DOI:10.1163/ 187631286X00099.

Nieukerken, E.J. van \& R. Johansson, 1990. Tribus Trifurculini. - In: R. Johansson, E.S. Nielsen, E.J. van Nieukerken \& B. Gustafsson (eds), The Nepticulidae and Opostegidae (Lepidoptera) of NW Europe. Fauna Entomologica Scandinavica 23: 239-321.

Nieukerken, E.J. van, E.S. Nielsen, R. Johansson \& B. Gustafsson, 1990. Introduction to the Nepticulidae. - In: R. Johansson, E.S. Nielsen, E.J. van Nieukerken \& B. Gustafsson (eds), The Nepticulidae and Opostegidae (Lepidoptera) of NW Europe. Fauna Entomologica Scandinavica 23: 11-109.

Nieukerken, E.J. van \& R. Puplesis, 1991. Taxonomy and distribution of the Trifurcula (Glaucolepis) raikhonae group (Lepidoptera: Nepticulidae). - Tijdschrift voor Entomologie 134(2): 201-210. http:// biostor.org/reference/49992.

Nieukerken, E.J. van, A. Laštůvka \& Z. Laštůvka, 2004. Annotated catalogue of the Nepticulidae and Opostegidae (Lepidoptera: Nepticuloidea) of the Iberian Peninsula. - SHILAP Revista de Lepidopterologia 32 (127): 211-260. http://redalyc.uaemex.mx/src/inicio/ ArtPdfRed.jsp?iCve $=45512710 \& i \mathrm{CveNum}=9283$.

Nieukerken, E.J. van, A. Laštůvka \& Z. Laštůvka, 2006. Annotated catalogue of the Nepticulidae and Oposte- gidae (Lepidoptera: Nepticuloidea) of France and Corsica. - Zootaxa 1216: 1-114. http://www.mapress. com/zootaxa/2006/zt01216p114.pdf.

Nieukerken, E.J. van, W. Biesenbaum \& W. Wittland, 2010. Die Gattung Trifurcula Zeller, 1848 in Deutschland mit zwei Erstnachweisen für die deutsche Fauna (Lep., Nepticulidae). The genus Trifurcula Zeller, 1848 in Germany with two first records for Germany (Lep., Nepticulidae). - Melanargia 22(1): 1-26. http://www. repository.naturalis.nl/record/364233.

Nieukerken, E.J. van, C. Doorenweerd, F.R. Stokvis \& D.S.J. Groenenberg, 2012. DNA barcoding of the leafmining moth subgenus Ectoedemia s. str. (Lepidoptera: Nepticulidae) with COI and EF1- $\alpha$ : two are better than one in recognising cryptic species. - Contributions to Zoology 81(1): 1-24. http://www.ctoz.nl/ctz/vol81/ nr01/art01.

Ratnasingham, S. \& P.D.N. Hebert, 2007. BOLD: The Barcode of Life Data System (www.barcodinglife.org). - Molecular Ecology Notes 7(3): 355-364. DOI:10. 1111/j.1471-8286.2006.01678.x.

Ronquist, F. \& J. Huelsenbeck, 2003. MrBayes 3: Bayesian phylogenetic inference under mixed models. - Bioinformatics 19(12): 1572-1574. DOI:10.1093/ bioinformatics/btg180.

Srivathsan, A. \& R. Meier, 2012. On the inappropriate use of Kimura-2-parameter (K2P) divergences in the DNA-barcoding literature. - Cladistics 28(2): 190194. DOI:10.1111/j.1096-0031.2011.00370.x.

Received: October 1, 2013

Accepted: October 9, 2013 